\title{
PENGARUH EFIKASI DIRI, LINGKUNGAN KELUARGA, DAN \\ PENGETAHUAN KEWIRAUSAHAAN TERHADAP MINAT BERWIRAUSAHA SISWA SMK DI SIDOARJO
}

\author{
Rifa'atul Maftuhah, Pascasarjana Unesa \\ rifa1986@yahoo.com \\ Bambang Suratman, Universitas Negeri Surabaya \\ bambang.1212@yahoo.com
}

\begin{abstract}
ABSTRAK
Penelitian ini bertujuan untuk menganalisis pengaruh efikasi diri, lingkungan keluarga, pengetahuan kewirausahaan terhadap minat berwirausaha siswa SMK di Sidoarjo. Populasi dalam penelitian ini adalah siswa kelas XI SMK di Sidoarjo kelompok Bisnis dan Manajemen tahun 2014-2015. Teknik pengambilan sampel dengan teknik proporsional sampling. Sampel terdiri dari 250 siswa. Metode analisis menggunakan teknik analisis regresi linier berganda. Hasil analisis data secara parsial efikasi diri berpengaruh signifikan positif terhadap minat berwirausaha siswa SMK di Sidoarjo, lingkungan keluarga secara parsial berpengaruh signifikan positif terhadap minat berwirausaha siswa SMK di Sidoarjo, dan pengetahuan kewirausahaan secara parsial berpengaruh signifikan positif terhadap minat berwirausaha siswa SMK di Sidoarjo. Kemudian hasil analisis data secara simultan efikasi diri, lingkungan keluarga dan pengetahuan kewirausahaan berpengaruh signifikan positif terhadap minat berwirausaha siswa SMK di Sidoarjo.
\end{abstract}

Kata-kata Kunci: Efikasi diri, lingkungan keluarga, pengetahuan kewirausahaan, minat berwirausaha

\begin{abstract}
This study aimed to analyze the influence of self-efficacy, family environment, and entrepreneurial knowledge towards the entrepreneurial interest of vocational school students in Sidoarjo. The population in this study are class XI student of SMK in Sidoarjo, Business and Management group 2014-2015. The sampling technique using proportional sampling technique. The sample consisted of 250 students. Methods of analysis using multiple linear regression. Results of the data shows that self-efficacy has partial positive significant effect on the interest in entrepreneurship of vocational school students in Sidoarjo. While the family environment has partial positive significant effect on entrepreneurial interest for vocational school students in Sidoarjo. Then entrepreneurial knowledge has partially positive significant effect on the interest in entrepreneurship vocational school students in Sidoarjo. Results of the data analysis shows that simultaneously self-efficacy, entrepreneurial knowledge, and family environment have a positive
\end{abstract}


significant effect on the interest in entrepreneurship of vocational school students in Sidoarjo.

Keywords: Self Efficacy, family environment, entrepreneurial knowledge, interest in entrepreneurship

\section{PENDAHULUAN}

Menurunnya tingkat pengangguran menunjukkan sudah mulai ada tindakan penanggulangan, meskipun masih kurang dari target yang diharapkan. Peningkatan jumlah angkatan kerja yang tidak signifikan terhadap peningkatan jumlah pekerja menggambarkan bahwa kompetisi di antara angkatan kerja semakin ketat. Pengangguran yang semakin meningkat dari tahun ke tahun dinilai pengamat sangat membutuhkan penanganan khusus, terutama bagi lulusan perguruan tinggi dan yang sederajat. Di antara upaya penanggulangan adalah meningkatkan kualitas sumber daya manusia, menciptakan lapangan kerja baru, dan menumbuhkembangkan usaha wiraswasta (Basrowi, 2011).

Kehadiran para wirausahawan menjadi unsur penting dalam menggerakkan roda ekonomi di negara maju. Mayoritas di negara maju, persentase pelaku wirausaha mencapai angka ideal, yaitu 2 hingga 4\%. Namun di Indonesia, sejauh ini masih minim. Menurut Menteri Koordinator Bidang Kesejahteraan Rakyat (Menko Kesra) HR Agung Laksono, salah satu faktor yang menyebabkan rendahnya tingkat persentase pelaku wirausaha di tanah air adalah masih kecilnya minat para lulusan lembaga pendidikan, baik tingkat sekolah maupun jenjang akademi dan perguruan tinggi untuk menjadi wirausahawan.

Minat berwirausaha lulusan SMA/SMK yang rendah ini merupakan masalah yang sangat serius. Menteri Koperasi dan UKM Syarifuddin Hasan mengungkapkan bahwa untuk memperkuat perekonomian dibutuhkan kemunculan para wirausahawan muda. Data yang didapat menunjukkan bahwa jumlah penduduk Indonesia mencapai kurang lebih 238 juta jiwa sedangkan jumlah wirausaha hanya $0,24 \%$ dari jumlah penduduk tersebut. Menurut Alma (2013), jika penduduk Indonesia kira-kira 238 juta jiwa, maka semestinya jumlah wirausaha di Indonesia harus mencapai 4,76 juta jiwa. Selain itu, manfaat adanya wirausaha adalah dapat memberikan lapangan pekerjaan, sehingga hal ini dapat mengurangi penggangguran.

Terdapat faktor-faktor yang mempengaruhi minat berwirausaha. Alma (2013) menyatakan bahwa ada tiga faktor yang mempengaruhi minat dalam berwirausaha yaitu: (1) personal, yang menyangkut aspek-aspek kepribadian seseorang; (2) sociological, yang menyangkut masalah hubungan dengan famili dan hubungan sosial lainnya; dan (3) environmental, yang menyangkut hubungan dengan lingkungan di antaranya pesaing, sumber daya, dan kebijakan pemerintah.

Berdasarkan hasil observasi guru Bimbingan Konseling (BK) pada beberapa siswa SMK berkaitan dengan minat mereka untuk menjadi wirausaha, diperoleh beberapa alasan kurangnya minat mereka menjadi wirausaha adalah 
dikarenakan mereka beranggapan bahwa seorang wirausaha harus mempunyai modal, kreativitas, dan cekatan. Selain itu, siswa merasa kurang percaya terhadap dirinya sendiri. Mereka merasa bahwa seorang wirausaha akan dihadapkan pada situasi yang tidak pasti, membutuhkan modal yang besar, penuh dengan tantangan, penghasilan tidak tetap, dan banyak resiko. Anggapan-anggapan tersebut menimbulkan perasaan takut gagal dan kekhawatiran siswa untuk bisa menjadi wirausahawan yang berhasil. Tentu jika fenemona tersebut tidak dicari solusinya, maka akan menjadi kendala bagi pertumbuhan ekonomi. Seperti diungkapkan oleh Shumpeter (Wibowo, 2011) bahwa faktor yang penting dalam pertumbuhan ekonomi suatu negara adalah adanya pengusaha yang mampu melakukan inovasi dan kreativitas.

Solusi alternatif yang dapat ditempuh untuk mengatasi permasalahan rendahnya minat berwirausaha siswa SMK di atas adalah dengan menumbuhkan minat berwirausaha dan menjadi wirausaha muda yang sangat dibutuhkan oleh negara pada saat sekarang ini. Wirausaha dapat dimaknai sebagai kemampuan melihat dan menilai peluang bisnis serta mengoptimalkan sumber daya yang ada serta berani dalam mengambil resiko.

Dalam penelitian Gibbs (2009) juga ditunjukkan bahwa efikasi diri berpengaruh terhadap minat berwirausaha. Dengan adanya efikasi diri yang tinggi maka akan menjadikan seseorang kreatif, dan semakin besar untuk mengejar peluang bisnis. Sejalan dengan hasil penelitian tersebut, Mobaraki (2012) mengungkapkan bahwa dengan efikasi diri yang tinggi, maka kepercayaan diri seseorang dalam membuka bisnis akan tinggi, sehingga kreativitasnya juga akan tinggi. Menurut Indarti (2008) Efikasi diri adalah kepercayaan seseorang atas kemampuannya untuk menyelesaikan suatu pekerjaan. Efikasi diri sangat menunjang kesuksesan seseorang yang dibentuk oleh 3 faktor yaitu: (1) melihat orang lain, (2) dukungan orang lain, (3) pengalaman.

Selain efikasi diri, terdapat beberapa faktor yang mempengaruhi minat berwirausaha, Menurut Lupiyohadi (2007) lingkungan keluarga merupakan lingkungan terdekat seorang wirausaha. Lingkungan keluarga berperan penting dalam pembentukan dan mendorong seseorang berwirausaha. Peran keluarga sangat penting dalam menumbuhkan minat berwirausaha bagi para siswa. Pendidikan berwirausaha dapat berlangsung sejak usia dini dalam lingkungan kelaurga. Melalui keluarga pola pikir kewirausahaan terbentuk, minat berwirausaha tumbuh dan berkembang dengan baik pada seseorang yang hidup dan tumbuh di lingkungan keluarga wirausahawan.

Berdasarkan hasil penelitian Zahariah (2010) diungkapkan bahwa faktor lingkungan berpengaruh terhadap berwirausaha. Hasil tersebut sejalan dengan Tong (2012) yang mengemukakan bahwa lingkungan berpengaruh terhadap minat berwirausaha. Lingkungan merupakan dorongan terdekat seseorang dalam berwirausaha. Hal senada juga diutarakan oleh Ajzen (2012) bahwa perilaku seseorang sangat dipengaruhi oleh norma subjektif yaitu tekanan dan dorongan 
dari lingkungan sosial terdekat seseorang untuk melakukan suatu perilaku dalam hal ini adalah kehendak atau niat untuk berwirausaha. Lingkungan sosial yang terdekat yang dimaksud tersebut adalah lingkungan keluarga dan lingkungan masyarakat tempat tinggal seseorang. Lingkungan keluarga dibentuk oleh 5 faktor yaitu: 1) Orang tua mengajarkan hidup mandiri sejak dini, 2) Relasi antar anggota keluarga, 3) Keadaan ekonomi keluarga, 4) Perhatian orang tua, 5) Latar belakang keluarga.

Selain efikasi diri dan lingkungan keluarga, pengetahuan kewirausahaan mempengaruhi minat berwirausaha. Pengetahuan kewirausahaan merupakan salah satu faktor pemicu minat berwirausaha. Seseorang yang telah memperoleh, pelatihan, mata kuliah, seminar, kursus kewirausahaan akan tertarik untuk berwirausaha (Saiman, 2009). Pengetahuan kewirausahaan dibentuk oleh 3 faktor yaitu: 1) pengetahuan dasar kewirausahaan, (2) pengetahuan ide dan peluang usaha, (3) pengetahuan tentang aspek-aspek usaha.

Di SMK pengetahuan kewirausahaan diberikan melalui mata pelajaran kewirausahaan dan pendidikan sistem ganda (PSG). Mata pelajaran kewirausahaan di SMK diberikan pada setiap tingkat dengan tujuan untuk mengembangkan sumber daya manusia sehingga mampu menciptakan pekerjaan bagi dirinya sendiri atau bahkan mampu menyediakan lapangan pekerjaan bagi orang lain. Pengetahuan tentang kewirausahaan yang diperoleh siswa juga kan membuka wawasan siswa dalam berwirausaha, mampu mengindetifikasi kegiatan dan peluang usaha dalam kehidupan sehari-hari, menanamkan sikap kewirausahaan, memberi bekal pengetahuan praktis, memberikan pengalaman awal berbisnis pada siswa serta mampu merencanakan bisnis apa yang dilakukan di masyarakat.

Menurut Yuwono (2008), minat berwirausaha adalah rasa tertariknya seseorang untuk melakukan kegiatan usaha yang mandiri dengan keberanian mengambil resiko. Minat berwirausaha dibentuk oleh 2 faktor yaitu: (1) Pengungkapan, (2) Tindakan. Dari uraian di atas, dapat disimpulkan bahwa minat wirausaha siswa dipengaruhi oleh efikasi diri (efikasi diri), pengetahuan kewirausahaan yang didapat di sekolah, dan lingkungan keluarga. Sehingga alternatif yang dapat ditempuh untuk pemecahan masalah mengenai rendahnya minat berwirausaha siswa adalah dengan menggunakan pendekatan enterpreneurial intention based models atau model yang dirancang untuk mendeteksi faktor-faktor yang mempengaruhi minat berwirausaha dengan pendekatan pendidikan.

Menurut pendekatan enterpreneurial intention based models, faktor-faktor yang mempengaruhi minat seseorang dalam berwirausaha adalah efikasi diri, pengetahuan kewirausahaan, dan lingkungan keluarga. Untuk itu, tujuan penelitian ini antara lain: 1) menganalisis pengaruh efikasi diri terhadap minat berwirausaha siswa SMK di Sidoarjo, 2)menganalisis pengaruh keluarga terhadap minat berwirausaha siswa SMK di Sidoarjo, 3) menganalisis pengaruh pengetahuan kewirausahaan terhadap minat berwirausaha siswa SMK di Sidoarjo, 
dan 4) menganalisis pengaruh efikasi diri, keluarga dan pengetahuan kewirausahaan secara simultan terhadap minat berwirausaha siswa SMK di Sidoarjo.

\section{METODE PENELITIAN}

Penelitian ini tergolong penelitian kuantitatif. Dalam penelitian ini menggunakan metode korelasi untuk mencari pengaruh antara variael bebas (independen) yaitu efikasi diri $\left(\mathrm{X}_{1}\right)$, lingkungan keluarga $\left(\mathrm{X}_{2}\right)$, dan pengetahuan kewirausahaan $\left(\mathrm{X}_{3}\right)$ terhadap variabel terikat (dependen) yaitu minat berwirausaha (Y). Populasi dalam penelitian ini adalah siswa kelas XI SMK di Sidoarjo kelompok bisnis manajemen terdiri dari 3 SMK yaitu SMK Diponegoro, SMK PGRI 2 Sidoarjo dan SMK Yos Sudarso Sidoarjo pada tahun ajaran 2014-2015 sebanyak 670 siswa. Sedangkan teknik pengambilan sampel dalam penelitian ini menggunakan proporsional sampling yaitu teknik pengambilan sampel dengan mempertimbangkan unsur-nsur dalam populasi penelitian. Pengambilan sampel menggunakan simple random sampling dengan acak tanpa memperhatikan strata atau tingkatan populasi tersebut (Sugiyono, 2011). Sehingga sampel yang diperoleh 250 siswa.

Metode pengumpulan data yang digunakan dalam penelitian ini adalah dokumentasi dan angket. Adapun metode analisis data yang digunakan adalah analisis regresi linier berganda. Analisis regresi linier berganda ini menggunakan uji asumsi klasik diantaranya uji normalitas, uji multikolinier, uji heteroskedastisitas, dan uji linieritas.

\section{HASIL DAN PEMBAHASAN}

Analisis dalam penelitian ini menggunakan analisis regresi linier berganda yang berfungsi untuk mengetahui ada tidaknya pengaruh signifikan antara ketiga variabel bebas yaitu efikasi diri $\left(\mathrm{X}_{1}\right)$, lingkungan keluarga $\left(\mathrm{X}_{2}\right)$, dan pengetahuan kewirausahaan $\left(\mathrm{X}_{3}\right)$ terhadap minat berwirausaha $(\mathrm{Y})$. Persamaan regresi yang diperoleh adalah sebagai berikut: $\mathrm{Y}=9,925+0,545 \mathrm{X}_{1}+0,144 \mathrm{X}_{2}+0,259 \mathrm{X}_{3}+$ ei. Dari persamaan tersebut dapat dijelaskan bahwa: 1) Konstanta yang dihasilkan sebesar 9,925. Hal ini menunjukkan bahwa besarnya minat berwirausaha adalah 9,925, jika variabel efikasi diri, lingkungan keluarga, dan pengetahuan kewirausahaan adalah nol. 2) Koefisien regresi variabel efikasi diri $\left(\mathrm{X}_{1}\right)$ yang dihasilkan sebesar positif 0,545 . Hal ini menunjukkan bahwa naiknya variabel efikasi diri menyebabkan minat berwirausaha akan naik dengan asumsi lingkungan keluarga dan pengetahuan kewirausahaan adalah konstan. 3) Koefisien regresi variabel lingkungan keluarga $\left(\mathrm{X}_{2}\right)$ yang dihasilkan sebesar 0,144 . Hal ini menunjukkan bahwa pengaruh yang timbul searah, dimana naiknya variabel lingkungan keluarga sebesar menyebabkan minat berwirausaha akan naik dengan asumsi efikasi diri dan pengetahuan kewirausahaan adalah konstan. 4) Koefisien 
regresi variabel pengetahuan kewirausahaan $\left(\mathrm{X}_{3}\right)$ yang dihasilkan sebesar 0,259. Hal ini menunjukkan bahwa naiknya variabel pengetahuan kewirausahaan menyebabkan minat berwirausaha akan naik dengan asumsi efikasi diri dan lingkungan keluarga adalah konstan.

Hasil uji hipotesis secara parsial menunjukkan nilai t hitung pada variabel efikasi diri $\left(\mathrm{X}_{1}\right)$ sebesar 6,291 dengan tingkat signifikansi lebih besar dari 5\% yaitu 0,000. Artinya efikasi diri secara parsial berpengaruh signifikan terhadap minat berwirausaha. Peningkatan efikasi diri meningkatkan minat untuk berwirausaha.

Berdasarkan hasil pengujian diperoleh hasil yang menunjukkan bahwa efikasi diri berpengaruh signifikan terhadap minat berwirausaha siswa SMK di Sidoarjo. Hasil tersebut mempunyai makna bahwa setiap perubahan variabel efikasi diri akan berpengaruh positif terhadap minat berwirausaha. Nilai koefisien regresi positif menunjukkan pengaruh yang timbul searah, dimana jika efikasi diri naik maka minat berwirausaha juga naik dengan asumsi variabel yang lain adalah konstan.

Hasil Penelitian ini menunjukkan bahwa efikasi diri berpengaruh terhadap minat berwiausaha siswa sesuai dengan penelitian yang dilakukan oleh Indarti (2008), salah satu faktor yang dapat mempengaruhi intensi seseorang dalam berwirausaha adalah efikasi diri. Menurut Drnovek et. al. (2009) mengemukakan bahwa efikasi diri melibatkan keyakinan individu mengenai kemampuan mereka untuk mencapai tujuan dan mengendalikan kognitif positif dan negatif seorang pengusaha selama proses memulai bisnis baru. Sedangkan menurut Chowdhury (2009) menyatakan bahwa efikasi diri adalah keyakinan seseorang terhadap kemampuan dirinya untuk melakukan sesuatu pekerjaan dan mendapatkan prestasi tertentu.

Hal ini didukung oleh Peng et. al. (2012) yang mengemukakan bahwa efikasi diri berpengaruh terhadap minat berwirausaha mahasiswa. Dengan didukung faktor-faktor yang lain, yaitu faktor psikologis, keluarga, lingkungan sosial, dan faktor pengalaman. Sementara itu, dalam penelitian Campo (2010) dapat ditunjukkan bahwa efikasi diri dapat memodifikasi keyakinan seseorang untuk memulai dan membangun bisnis baru. Seperti yang diuraikan oleh Bandura (1997), bahwa efikasi diri dikenal dengan teori kognitif sosial yang merujuk pada keyakinan individu bahwa ia mampu untuk mengerjakan suatu tugas. Dikatakan sosial karena kegiatan manusia berawal dari apa yang dipelajari dilingkungan dimana ia berada.

Dalam penelitian Gibbs (2009) juga ditunjukkan bahwa efikasi diri berpengaruh terhadap minat berwirausaha. Dengan adanya efikasi diri yang tinggi maka akan menjadikan seseorang kreatif, dan semakin besar untuk mengejar peluang bisnis. Sejalan dengan hasil penelitian tersebut, Mobaraki (2012) mengungkapkan bahwa dengan efikasi diri yang tinggi, maka kepercayaan diri 
seseorang dalam membuka bisnis akan tinggi, sehingga kreativitasnya juga akan tinggi.

Efikasi diri pada penelitian ini memiliki tiga indikator yaitu kemampuan melihat orang lain, dukungan orang lain dan pengalaman. Berdasarkan jawaban yang diberikan responden pada indikator melihat orang lain menunjukkan rerata 4,27 dengan kategori tinggi yang artinya siswa akan termotivasi setelah melihat kemampuan orang lain. Selanjutnya adalah indikator dukungan orang lain menunjukkan rerata 3,73 dengan kategori tinggi yang artinya siswa memiliki dukungan yang tinggi terhadap orang lain. Kemudian indikator yang terakhir adalah pengalaman menunjukkan rerata 3,64 dengan kategori tinggiyang artinya siswa memiliki pengalaman dalam berwirausaha.

Berdasarkan uraian diatas maka dapat disimpulkan bahwa efikasi diri yang dimiliki siswa baik maka minat berwirausaha yang dimiliki juga akan semakin baik. Hal ini dikarenakan efikasi diri siswa dapat mempengaruhi seseorang terhadap kemampuan dirinya untuk memulai usaha.

Hasil uji hipotesis secara parsial menunjukkan nilai t hitung pada variabel lingkungan keluarga $\left(\mathrm{X}_{2}\right)$ sebesar 2,071 dengan tingkat signifikansi lebih besar dari 5\% yaitu 0,039. Artinya lingkungan keluarga secara parsial berpengaruh signifikan terhadap minat berwirausaha. Peningkatan lingkungan keluarga meningkatkan minat untuk berwirausaha.

Berdasarkan hasil pengujian diperoleh hasil yang menunjukkan bahwa lingkungan keluarga berpengaruh signifikan terhadap minat berwirausaha siswa SMK di Sidoarjo. Hasil tersebut mempunyai makna bahwa setiap perubahan variabel lingkungan keluarga akan berpengaruh positif terhadap minat berwirausaha. Nilai koefisien regresi positif menunjukkan pengaruh yang timbul searah, dimana jika lingkungan keluarga naik maka minat berwirausaha juga naik dengan asumsi variabel yang lain adalah konstan.

Hasil Penelitian ini menunjukkan bahwa lingkungan keluarga berpengaruh terhadap minat berwiausaha siswa sesuai dengan penelitian yang dilakukan Zahariah (2010) bahwa terdapat beberapa faktor yang mempengaruhi minat berwirausaha mahasiswa malaysia diantaranya faktor lingkungan, lingkungan berpengaruh terhadap berwirausaha. Sedangkan Menurut Costa (2009) menyatakan bahwa lingkungan keluarga merupakan faktor yang menentukan dalam minat berwirausaha siswa, peran keluarga juga sangat penting dalam menumbuhkan minat berwirausaha bagi para siswa. Sedangkan hasil penelitian Putra (2012) menyatakan bahwa salah satu faktor penentu minat mahasiswa berwirausaha adalah faktor lingkungan keluarga mahasiswa yang familiar.

Lingkungan keluarga pada penelitian ini memiliki lima indikator yaitu orang tua mengajarkan hidup sejak dini, relasi antar anggota keluarga, keadaan ekonomi keluarga, perhatian orang tua dan latar belakang keluarga. Berdasarkan jawaban yang diberikan responden pada indikator orang tua mengajarkan hidup mandiri sejak dini menunujukkan rerata 4,27 dengan kategori sangat tinggi yang artinya 
orang tua siswa mengajarkan hidup mandiri sejak dini. Selanjutnya adalah perhatian orang tua menunjukkan rerata 3,98 dengan kategori tinggi yang artinya perhatian orang tua siswa tinggi. Indikator yang ketiga adalah relasi antar anggota keluarga menunjukkan rerata 3,73 dengan kategori tinggi yang artinya relasi antar anggota keluarga tinggi. Indikator keempat adalah latar belakang keluarga menunjukkan rerata 3,23 dengan kategori cukup yang artinya latar belakang keluarga cukup dalam berwirausaha. Sedangkan indikator yang terakhir adalah keadaan ekonomi keluarga menunjukkan rerata 3,16 dengan kategori cukup yang artinya siswa berasal dari keluarga yang cukup. Berdasarkan uraian di atas maka dapat disimpulkan bahwa lingkungan yang dimiliki siswa baik, orang tua memberikan kebebasan pada anak untuk belajar sesuai dengan keinginan dan kemampuannya, tetapi juga memberikan arahan dan bimbingan.

Hasil uji hipotesis secara parsial menunjukkan nilai t hitung pada variabel pengetahuan kewirausahaan $\left(\mathrm{X}_{3}\right)$ sebesar 2,355 dengan tingkat signifikansi lebih besar dari 5\% yaitu 0,019. Artinya pengetahuan kewirausahaan secara parsial berpengaruh signifikan terhadap minat berwirausaha. Peningkatan pengetahuan kewirausahaan meningkatkan minat untuk berwirausaha.

Berdasarkan hasil analisis menunjukkan bahwa pengetahuan kewirausahaan berpengaruh signifikan terhadap minat berwirausaha siswa SMK di Sidoarjo. Hasil tersebut mempunyai makna bahwa setiap perubahan variabel pengetahuan kewirausahaan akan berpengaruh positif terhadap minat berwwirausaha. Nilai koefisien regresi menunujukkan pengaruh yang timbul searah, dimana jika variabel pengetahuan kewirausahaan naik, maka minat berwirausaha juga naik dengan asumsi variabel yang lain adalah konstan.

Hasil penelitian ini berbanding terbalik dengan hasil penelitian dilakukan oleh Abdullah (2013) dalam penelitiannya menyimpulkan bahwa pengetahuan tidak berpengaruh terhadap minat berwirausaha mahasiswa perguruan tinggi negeri (PTN), tetapi berpengaruh terhadap mahasiswa perguruan tinggi swasta (PTS). Hal ini sejalan dengan penelitian Roxas (2008) yang mengungkapkan bahwa pengetahuan tidak berpengaruh terhadap minat berwirausaha pemuda di Pahang Malaysia. Sedangkan menurut Kuntowicaksono (2012) yang menunjukkan bahwa pengetahuan tidak berpengaruh terhadap minat berwirausaha, hal ini dikarenakan pengetahuan saja tidak cukup untuk menjadi modal seseoarang dalam menjalankan wirausaha akan tetapi seseorang harus mampu melihat kondisi nyata yang terjadi di lapangan atau dipasar sehingga dapat menentukan strategi-strategi yang akurat dalam menjalankan bisnis.

Berbeda dengan hasil penelitian yang dilakukan oleh Oriarewo (2013) dan Pihie (2013) yang menyatakan bahwa pengetahuan berpengaruh terhadap niat berwirausaha. Pengetahuan dapat diperoleh dari kursus sehingga berdampak untuk memulai bisnis. Hal ini sesuai dengan penelitian Aprilianty (2012) yang menyatakan bahwa pengetahuan berpengaruh terhadap minat berwirausaha. Berarti minat berwirausaha akan meningkat apabila pengetahuan kewirausahaan 
ditingkatkan. Semakin tinggi pengetahuan kewirausahaan, semakin tinggi pula minat berwirausaha siswa.

Pengetahuan kewirausahaan pada penelitian ini memiliki tiga indikator yaitu pengetahuan dasar kewirausahaan, pengetahuan ide dan peluang usaha, dan pengetahuan tentang aspek-aspek usaha. Berdasarkan jawaban yang diberikan responden pada indikator pengetahuan tentang aspek-aspek peluang usaha menunjukkan rerata 3,72 dengan kategori tinggi yang artinya bahwa siswa memiliki pengetahuan tentang aspek-aspek usaha tinggi dalam berwirausaha. Selanjutnya adalah indikator pengetahuan dasar kewirausahaan menunjukkan rerata 3,63 dengan kategori tinggi yang artinya pengetahuan dasar kewirausahaan siswa tinggi dalam berwirausaha. Dan indikator yang terakhir adalah pengetahuan ide dan peluang usaha menunjukkan rerata 3,40 dengan kategori tinggi yang artinya pengetahuan iden dan peluang usaha siswa tinggi terhadap berwirausaha.

Berdasarkan uraian di atas maka dapat disimpulkan bahwa pengetahuan kewirausahaan yang dimiliki siswa baik, sehingga informasi atau pengetahuan yang ada akan menciptakan suatu proses melalui berbagai hambatan serta resiko yang akan dilalui untuk menyusun usaha.

Dari hasil uji signifikansi simultan dengan uji f diperoleh hasil bahwa ketiga variabel bebas efikasi diri, lingkungan keluarga, dan pengetahuan kewirausahaan berpengaruh secara simultan terhadap minat berwirausaha. Hal ini terlihat dari nilai $\mathrm{F}$ hitung yaitu 19,287 > 2,6413 dengan nilai signifikansi $\mathrm{p}=0,000<0,05$. Sehingga HO ditolak, yang artinya variabel efikasi diri, lingkungan keluarga, dan pengetahuan kewirausahaan secara bersama-sama mempunyai pengaruh yang signifikan terhadap minat berwirausaha siswa SMK di Sidoarjo. Hal ini berarti semakin baik efikasi diri, lingkungan keluarga, dan pengetahuan kewirausahaan siswa SMK di Sidoarjo, maka semakin baik pula minat berwirausaha siswa.

Efikasi diri, lingkungan keluarga, dan pengetahuan kewirausahaan berpengaruh signifikan pada minat didukung temuan dilapangan yaitu minat kewirausahaan siswa dibentuk dari efikasi diri yang diperoleh keyakinan diri siswa dalam melaksanakan tugas-tugas yang telah diberikan, selain itu dengan adanya dukungan keluarga yang memberikan pengaruh terhadap jenis pekerjaan anak dimasa yang akan datang, sehingga keluarga dapat dijadikan pembimbing untuk mengembangkan kreativitas anak. Selain efikasi diri, lingkungan keluarga, dan pengetahuan kewirausahaan juga diperlukan. Pengetahuan kewirausahaan diperoleh melalui kegiatan belajar mengajar dan simulasi kegiatan praktek kewirausahaan yang mengharuskan mereka untuk menciptakan suatu usaha baru atau lama yang dikembangkan.

\section{SIMPULAN}

Kesimpulan dari penelitian ini antara lain: 1) Efikasi diri berpengaruh positif terhadap minat berwirausaha siswa SMK di Sidoarjo. Maksudnya bahwa efikasi diri secara parsial berpengaruh signifikan terhadap minat berwirausaha, yang 
berarti jika variabel efikasi diri $\left(\mathrm{X}_{1}\right)$ naik maka minat berwirausaha juga akan naik dengan asumsi bahwa variabel lingkungan keluarga dan pengetahuan kewirausahaan adalah konstan. 2) Lingkungan keluarga berpengaruh positif terhadap minat berwirausaha siswa SMK di Sidoarjo. Maksudnya bahwa lingkungan keluarga secara parsial berpengaruh signifikan terhadap minat berwirausaha, yang berarti jika variabel lingkungan keluarga $\left(\mathrm{X}_{2}\right)$ naik maka minat berwirausaha juga akan naik dengan asumsi bahwa variabel efikasi diri dan pengetahuan kewirausahaan adalah konstan. 3) Pengetahuan kewirausahaan berpengaruh positif terhadap minat berwirausaha siswa SMK di Sidoarjo. Maksudnya pengetahuan kewirausahaan secara parsial berpengaruh signifikan terhadap minat berwirausaha, yang berarti jika variabel pengetahuan kewirausahaan $\left(\mathrm{X}_{3}\right)$ maka minat berwirausaha juga akan naik dengan asumsi bahwa variabel efikasi diri dan lingkungan keluarga adalah konstan. 4) Efikasi diri, lingkungan keluarga dan pengetahuan kewirausahaan berpengaruh positif terhadap minat berwirausaha siswa SMK di Sidoarjo. Hal ini berarti bahwa efikasi diri, lingkungan keluarga dan pengetahuan kewirausahaan secara simultan berpengaruh signifikan terhadap minat berwirausaha. Semakin tinggi efikasi diri, lingkungan keluarga dan pengetahuan kewirausahaan maka semakin tinggi minat berwirausaha siswa SMK di Sidoarjo. Saran yang dapat diberikan antara lain: 1) Sebaiknya siswa tetap memiliki keyakinan terhadap kemampuan sesuai dengan bidang keahlian masing-masing sehingga dapat menyelesaikan perkerjaan ataupun tugas-tugasnya sesuai dengan kompetensi keahlian. 2) Hendaknya keluarga memberikan dorongan dan membiasakan anak dalam berwirausaha. 3) Pengetahuan kewirausahaan yang diterima siswa disekolah dapat di aplikasikan dalam berwirausaha dengan ditunjang bidang keahlian masing-masing.

\section{DAFTAR RUJUKAN}

Abdullah, Abdul Aziz N. N, 2013. Factors That Influence the Interest of Youths in Agricultural Entrepreneurship. International Journal of Business and Social Science, 288-302.

Ajzen, Fishbein, M. \&W, 2012. Belief, Attitude, Intention, and Behavior: An Introduction to Theory and Research. Reading, MA: Addison-Wesley. Callifornia: Addison-Wesley.

Alma, Buchari, 2013. Kewirausahaan, Edisi I, Cetakan Delapan Belas. Bandung: Alfabeta.

Aprilianty, Eka, 2012. Pengaruh Kepribadian Wirausaha, Pengetahuan Kewirausahaan dan Lingkungan Terhadap Minat Berwirausaha Siswa SMK Muhammadiyah. Jurnal Pendidikan Vokasi, Volume 2 No. 3

Roxas, Banjo G. R. C, 2008. Entrepreneurial Knowledge and its Effects on entrepreneurial intentions: Development of a conceptual framework. Asia Pacific Social Science, 61-77.

Bandura, A, 1997. Self efficacy the exercise of control. New York: Freeman. 
Basrowi, 2011. Kewirausahaan, Edisi Pertama. Bogor: Ghalia Indonesia.

Chowdhury, M. S, 2009. Human Behavior In The Context of Training: An Overview Of The Role of Learning Theories as Applied to Training and Development. Chowdhury, M. S, \& College, M. 2006. Human Behavior In The Context of Training: An Overview Of The Role of Learning TJournal of Knowledge Management Practice, 50-62.

Costa, Francisco José da A. A, 2009. Factors of influence on the entrepreneurial interst: An analysis with students of information technology related courses. Journal of information systems and technology management, 227-246.

Gibbs, S. R, 2009. Exploring the influence of task specific self efficacy on opportunity recognition perceptions and behaviors. Frontiers of entrepreneurship research, 29.

Oriarewo, Godday Orziemgbe K. C, 2013. Entrepreneurial Perceptions and Knowledge among Graduates of Nigerian Universities. International Journal of Scientific and Research Publications.

Kuntowicaksono, 2012. Pengaruh pengetahuan kewirausahaan dan kemampuan memecahkan masalah wirausaha terhadap minat berwirausaha siswa Sekolah Menengah Kejuruan. Journal Economic Education, 45-52.

Lupiyohadi, R, 2007. Entrepreneurship: From Mindset to Strategy. Jakarta: LP FE UI.

Drnovsek et al, 2009. Entrepreneurial self efficacy and business start up: developing a multi dimensional definition. Emeraldinsight.

Mobaraki, Mohammad Hasan Y. B, 2012. Designing pattern of entrepreneurial self efficacy on entrepreneurial intention. Information management and business Review, 428-433.

Indarti, R, 2008. Intensi kewirausahaan mahasiswa: Studi Perbandingan Antara Indonesia, jepang, dan Norwegia. Jurnal Ekonomika dan Bisnis Indonesia, $1-27$.

Peng, et al, 2012. Entrepreneurial Intentions and Its Influencing Factors: A Survey of the University Students in Xi' an China. Scientific research, 95-100.

Phie, Zaidatol Akmaliah Lope, 2013. Knowledge of cognition and entrepreneurial intentions: Implications for learning entrepreneurship in public and private universities. Sciencedirect, 174-181.

Putra, Aditia, R. 2012. Faktor-faktor penentu minat mahasiswa manajemen untuk berwirausaha manajemen untuk berwirausaha. Jurnal manajemen, Volume 01 Nomor 01.

Saiman, L, 2009. Kewirausahaan teori, praktik dan kasus-kasus. Jakarta: Salemba Empat.

Sugiyono, 2011. Metode Penelitian Administrasi Dilengkapi dengan Metode $R \& D$. Bandung: CV. Alfabeta.

Tong, Xue Fa, 2011. Factors influence entrepreneurial intention among University Students. International journal of social and humanity studies.

Wibowo, A, 2011. Pendidikan kewirausahaan. Yogyakarta: Pustaka pelajar.

Yuwono, S. P, 2008. Pengaruh Pelatihan Kewirausahaan Terhadap Tumbuhnya Minat Berwirausaha. Jurnal Penelitian Humaniora, 119-127.

Zahariah Mohd Zain, A. M, 2010. Entrepreneurship intention among Malaysian Business Students. Candian Social Science, 34-44. 